\title{
New Report of the Varunid Crabs, Hemigrapsus takanoi and Sestrostoma toriumii (Crustacea: Decapoda: Varunidae) from Korea
}

\author{
Sanghui Lee ${ }^{1}$, Sang-kyu Lee ${ }^{2}$, Hyun Soo Rho ${ }^{3}$, Won Kim", \\ 'School of Biological Sciences, Seoul National University, Seoul 151-747, Korea \\ ${ }^{2}$ Marine Ecosystem Research Division, Korea Institute of Ocean Science and Technology, Ansan 426-744, Korea \\ ${ }^{3}$ Dokdo Research Center, Korea Institute of Ocean Science and Technology, Uljin 767-813, Korea
}

\begin{abstract}
As a result of continuous taxonomic studies on the Korean crabs, two varunid crabs, Hemigrapsus takanoi Asakura and Watanabe, 2005 and Sestrostoma toriumii (Takeda, 1974), are newly reported from Korean waters. Hemigrapsus takanoi, as a sibling species of H. penicillatus, has not been recognized in Korean waters, and this species occurs in the sympatric habitat with H. penicillatus in the Korean peninsula. Sestrostoma toriumii (Takeda, 1974) is associated with thallassinid Upogebia major (De Haan, 1841) and echiuran Urechis unicintus (Von Drache, 1881) as the case of S. balssi (Shen, 1932). The Korean S. toriumii showed smaller size than those mentioned in the original description. Their illustrations and pictures are provided with descriptions, and the distributions of these species in the Korean peninsula are also provided.
\end{abstract}

Keywords: Hemigrapsus takanoi, Sestrostoma toriumii, Varunidae, Decapoda, Korean fauna

\section{INTRODUCTION}

The members of the family Varunidae are familiar in the intertidal zone. They live in crevices and under stones on rocky shores or burrow into soft sediments. As a result of the ongoing inventory work on the Korean crabs deposited in the Laboratory of Systematics and Molecular Evolution, Seoul National University, revealed that two crabs, Hemigrapsus takanoi Asakura and Watanabe, 2005 and Sestrostoma toriumii (Takeda, 1974), are new to the Korean decapod fauna.

Hemigrapsus penicillatus s. 1. was one of the most common crabs in the Korean intertidal zone. Takano et al. (1997) found that $H$. penicillatus $\mathrm{s}$. 1 . is divided into two species by protein electrophoretic analysis. In the recent work, Hemigrapsus takanoi Asakura and Watanabe, 2005 is separated from $H$. penicillatus by some morphological characters, size of setal patches and patterns of spots (Asakura and Watanabe, 2005). Yamasaki et al. (2011) distinguished these sibling species by the molecular based method. We examined $H$. penicillatus s. 1. deposited in the Laboratory of Systematics and Molecular Evolution, Seoul National University from 1954 to 2011. As a result, we separated 743 individuals of
H. penicillatus and 808 individuals of $H$. takanoi from our speciemens. Now, the genus Hemigrapsus Dana, 1851 in Korea is composed of five species: H. longitarsis (Miers, 1879), H. penicillatus (De Haan, 1835), H. sanguineus (De Haan, 1835), H. sinensis Rathbun, 1929 and H. takanoi Asakura and Watanabe, 2005.

Three species of the genus Sestrostoma have been recorded worldwide (Ng et al., 2008): Sestrostoma balssi (Shen, 1932), S. depressum (Sakai, 1965), and S. toriumii (Takeda, 1974). The members of the genus Sestrostoma occur in the burrows of thallassinids, callianassids and echiurans (Davie, 1992; Sakai, 2000; Anker et al., 2005). Of these, only Sestrostoma balssi was recorded in Korean fauna (Kim, 1973). During the ongoing study on the Korean crabs, Sestrostoma toriumii (Takeda, 1974) were collected. The descriptions and the illustrations of Hemigrapsus takanoi and Sestrostoma toriumii are provided herein.

\section{MATERIALS AND METHODS}

The specimens examined in this study were preserved in $70 \%$
(C) This is an Open Access article distributed under the terms of the Creative Commons Attribution Non-Commercial License (http://creativecommons.org/ licenses/by-nc/3.0/) which permits unrestricted non-commercial use, distribution, and reproduction in any medium, provided the original work is properly cited.

pISSN 2234-6953 eISSN 2234-8190
*To whom correspondence should be addressed

Tel: 82-2-880-6695, Fax: 82-2-872-1993

E-mail:wonkim@plaza.snu.ac.kr 
ethyl alcohol. All drawings were prepared using camera lucida on a Nikon SMZ800 (Nikon, Tokyo, Japan). All characters were measured using a digital slide caliper Mitutoyo CD6CSX (Mitutoyo, Kawasaki, Japan) to the nearest $0.1 \mathrm{~mm}$. The abbreviations CW, CL, and G1 refer to the carapace width, carapace length and first gonopod of the male, respectively. The width of the carapace was measured across the widest breadth including the longest anterolateral tooth on each side. The length of the carapace was measured across the middle of the carapace from the tip of the longest lobe of the frontal border to the posterior border, including any tubercles along the posterior border. The specimens examined in the present study are deposited in the Marine Arthropod Depository Bank of Korea (MADBK), Seoul National University.

\section{SYSTEMATIC ACCOUNTS}

Order Decapoda Latreille, 1802

Superfamily Grapsoidea Macleay, 1838

Family Varunidae H. Milne Edwards, 1853

Genus Hemigrapsus Dana, 1851

${ }^{1 *}$ Hemigrapsus takanoi Asakura and Watanabe, 2005 (Figs. 1, 2)

Grapsus (Eriocheir) penicillatus De Haan, 1835: 60, Pl. 11, fig. 5 (in part).

Hemigrapsus penicillatus: Miyake et al., 1962 (in part); Kim, 1973: 473, Pl. 42, fig. 159 (in part); Sakai, 1976: 650, Pl. 222, fig. 2 (in part).

Hemigrapsus takanoi Asakura and Watanabe, 2005: 279, figs. $1-7$.

Material examined. Korea: $31 \sigma^{\top} \sigma^{7}, 28$ 우 우, Incheon, 6 Jun 1954; $2 \sigma^{\nearrow} \sigma^{\nearrow, ~} 66$ 우 우, Chungcheongnam-do: Boryeongsi, Daecheon-dong, 25 Jul 1957; $6 \sigma^{\top} \sigma^{7}$, 1 우, Taean-gun, Anmyeon-eup, 12 May 1964; 105 『 ア Incheon, 14 Apr 1968; $1 \sigma^{\top}$, Jeollanam-do: Yeosu-si, Dolsan-eup, 14 Jun 1969; $2 \sigma^{\top} \sigma^{\top}$, Jeju-do: Jeju-si, Iho-dong, 11 Aug 1969; $12 \sigma^{\nearrow} \sigma^{\top}$, 10 우 우, Incheon, 25 Apr 1970; 42 징, 10 우 우, Incheon, 9

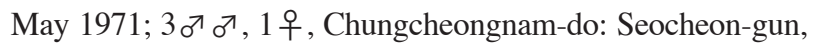
Biin-myeon, 20 Jul 1971; 3 శ $^{\nearrow} \sigma^{\nearrow}, 2$ 우 우, Seocheon-gun, Biinmyeon, 23 Jul 1971; $2 \sigma^{\nearrow}$ ๙ 3 우 우, Jeollabuk-do: Buan-gun, Wido-myeon, 13 Apr 1972; 2 『

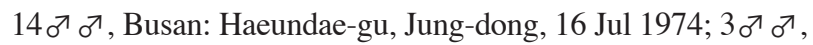
Jeollanam-do: Jindo-gun, 3 Aug 1974; 10 유 끼, 4 우 우, Jeollabuk-do: Buan-gun, 8 May 1978; $3 ठ^{\nearrow}$ ఠ , Busan: Gangseo-gu, Songjeong-dong, 24 May 1978; 1 『 , Gyeongsangnam-do:
Namhae-gun, Sangju-myeon, Sangju-ri, 8 Oct 1978; 1 万๐, 3 우 우, Gimhae-si, Jillye-myeon, Songjeong-ri, 31 Oct 1978; 17 지 ㅈ, 14 우 우, Jeollabuk-do: Gunsan-si, Okdo-myeon, 25 Jul 1980; $2 \sigma^{\nearrow}$ ๙ Gyeongsangbuk-do: Yeongdeok-gun, Ganggu-myeon, Opo-ri, 12 Aug 1982; $4 \sigma^{\nearrow} \sigma^{\nearrow}, 4$ 우 우, Busan, Sahagu, Dadae-dong, 27 Aug 1984; $4 \sigma^{\nearrow}$ 『, Jeollanam-do: Jindogun, 25 Jul 1994; 28 ఠ Љ

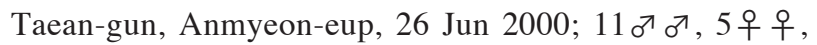
Taean-gun, Anmyeon-eup, 27 Jul 2000; $1 \sigma^{7}$, Seosan-si, Daesan-eup, Ungdo-ri, 30 Jun 2000; $2 \sigma^{\top} \sigma^{\top}, 1$ 우, Taean-gun, Anmyeon-eup, 1 Jul 2000; $3 \sigma^{\top} \sigma^{\top}$, 4 우 우, Jeollanam-do: Haenam-gun, Hwawon-myeon, Jugwang-ri, 27 Aug 2000; $3 \sigma^{\nearrow} \sigma^{\nearrow,}$ 2 우 우, Gyeonggi-do: Hwaseong-si, Ujeong-eup, Hogok-ri, 29 Sep 2000; $1 \sigma^{\top}, 1$ 우, Hwaseong-si, Ujeong-eup, Hogok-ri,

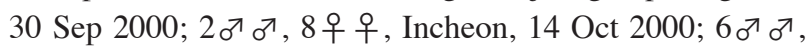
5 우 우, Jeollanam-do: Goheung-gun, Bongnae-myeon, 20 Oct 2001; $4 \sigma^{\nearrow} \sigma^{\nearrow}$, Chungcheongnam-do: Seosan-si, Daesaneup, Ungdo-ri, 22 Jun 2002; 1 ð , Jeollabuk-do: Buan-gun,

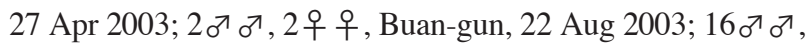
10 우 우, Buan-gun, 23 Aug 2003; 96 ఠ $\varnothing^{7}, 63$ 우 우, Incheon, 24 Jan 2006; 21 ఠ ఠ , Gyeongsangnam-do: Goseong-gun, Donghae-myeon, Yongjeong-ri, 25 Apr 2009; $3 \sigma^{\nearrow} \sigma^{\nearrow}$, Masan-

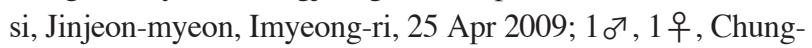
cheongnam-do: Seocheon-gun, Seo-myeon, Wolho-ri, 14 May 2009; $24 \sigma^{\nearrow} \sigma^{\nearrow, ~ G y e o n g s a n g b u k-d o: ~ P o h a n g-s i, ~ N a m-g u, ~}$ Daebo-myeon, Daebo-ri, 10 Oct 2009; $21 \sigma^{7} \nwarrow^{7}, 15$ 우 우, Jeollanam-do: Jindo-gun, 15 Jun 2011; 8 지 지, 6 우 우, Chungcheongnam-do: Taean-gun, Nam-myeon, Mongsan-ri, 17 Jun 2011.

Comparative materials. Hemigrapsus penicillatus: Korea: $2 \sigma^{\nearrow}$, Incheon, 6 Jun 1954; 4 ఠ す Incheon, 14 Apr 1968; 1 ऽ, Jeollanam-do: Yeosu-si, Dolsan-eup, 14 Jun 1969; $2 \sigma^{\nearrow} \sigma^{\nearrow}, 3$ 우 우, Jeju-do: Jeju-si, Chuja-myeon, 10 Aug 1969; 1 ๙ , Jeju-si, Samyang-dong, 12 Aug 1969; 3 ठ ठ , Seogwiposi, 15 Aug 1969; 4 ఠ Љ , 2 우 우, Seogwipo-si, 10 Aug 1970; $2 \sigma^{\nearrow}$, Incheon, 17 Jul 1973; $3 \sigma^{\nearrow}$ ๙ , Busan: Haeundae-gu, Jung-dong, 16 Jul 1974; 1 ग , Jeollanam-do: Jindo-gun, 3 Aug 1974; 1 ð , Busan: Gangseo-gu, Songjeong-dong, 24 May 1978; 1 ग , Gangwon-do: Gangneung-si, 5 Oct 1981; 2 ণ ণ , Gyeongsangbuk-do: Yeongdeok-gun, Ganggu-myeon, Opo-ri, 12 Aug 1982; 3 ๙ ๙ Uljin-gun, Jukbyeon-myeon, 15 Aug 1982; $3 \sigma^{\nearrow} \sigma^{\top}, 1$ 우, Jeju-do: Jeju-si, Chuja-myeon, 15 Jul 1985; 2 ఠ ठ , Seogwipo-si, 28 Jun 1992; 9 ठ ठ , Jeollanam-do: Jindo-gun, 25 Jul 1994; 1 ఠ, Docho-myeon, Uido-ri, 14 Aug 1998; $1 \Im^{\top}$, Jeollabuk-do: Buan-gun, Gyehwamyeon, 28 Sep 2003; 1 『 , Jeollanam-do: Jindo-gun, 29 Jun 2004; 2 ठ ठ , Gyeongsangnam-do: Geoje-si, Hacheongmyeon, 29 Aug 2005; 1 ð, Namhae-gun, 31 Aug 2005; $3 \sigma^{\nearrow}$ ð, Jeollanam-do: Yeosu-si, Dolsan-eup, 1 Sep 2005; $1 \overbrace{}^{\nearrow}$, Jeju-

Korean name: ${ }^{1 *}$ 털다발풀게 (신칭) 

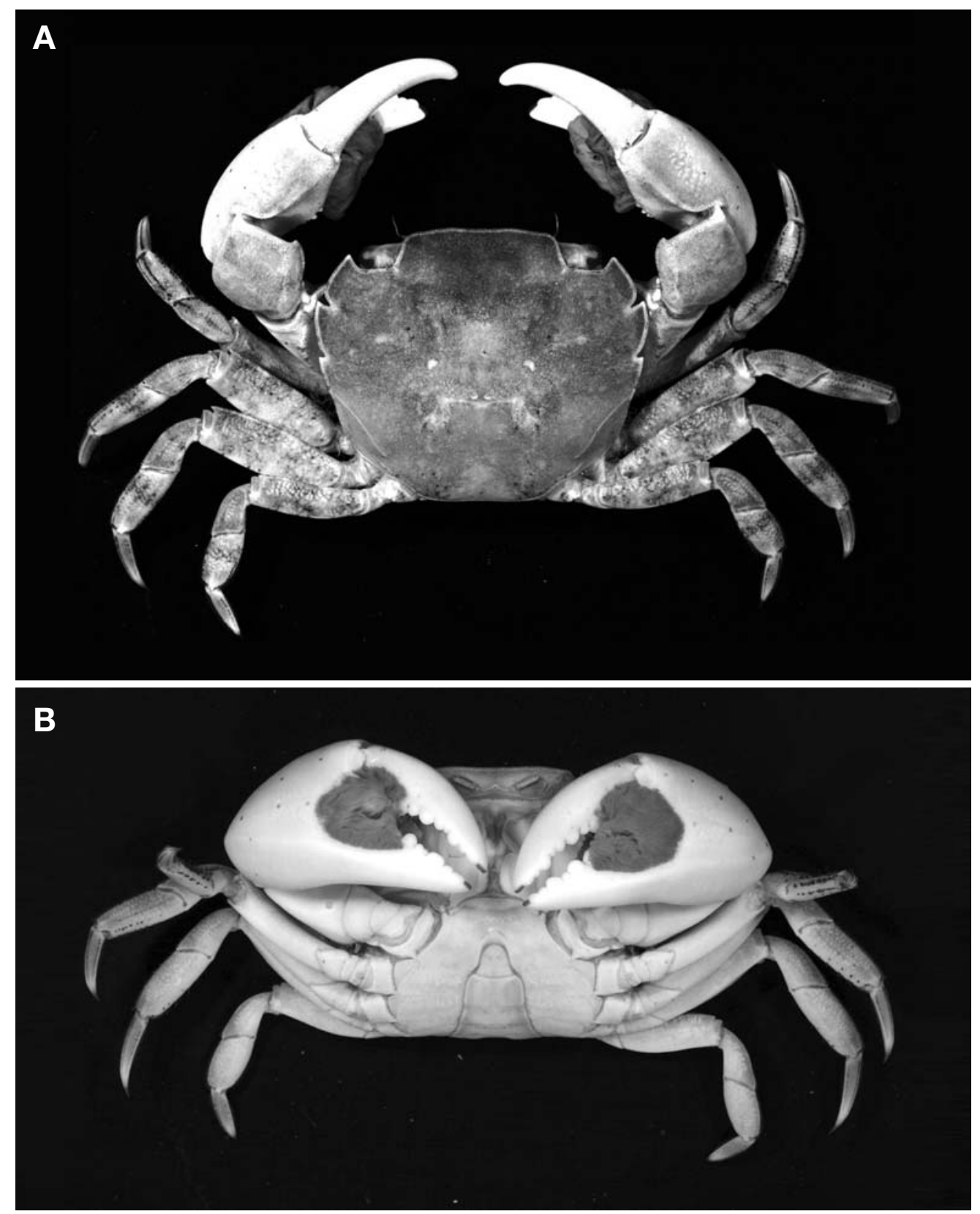

Fig. 1. Hemigrapsus takanoi Asakura and Watanabe, 2005, male (CL $19.4 \mathrm{~mm}, \mathrm{CW} 22.4 \mathrm{~mm})$. A, Dorsal view; $B$, Ventral view. CL, carapace length from the front to the posterior dorsal margin of the carapace; CW, width of the carapace measured at the widest part.

do: Seogwipo-si, 17 Oct 2005; 13 ఠ 17 Oct 2005; $2 \diamond^{\nearrow}$ Љ, Jeju-si, Hangyeong-myeon, Sinchangri, 25 Oct 2005; $3 \sigma^{\nearrow} \sigma^{\top}, 1$ 우, Gujwa-eup, Hado-ri, 26 Oct 2005; 24 శ $\sigma^{7}, 5$ 우 우, Gujwa-eup, Gimnyeong-ri, 27 Oct

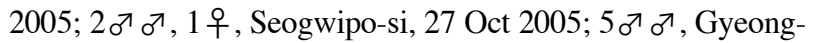
sangnam-do: Geoje-si, Hacheong-myeon, 11 May 2006; $19 \sigma^{\nearrow} \sigma^{\nearrow}, 17$ 우 우, Jeju-do: Seogwipo-si, 13 Oct 2006; 4 శ $\sigma^{\nearrow}$, 2 우 우, Jeju-si, Udo-myeon, 14 Oct 2006; 33 이 지, 5 우 우,
Seogwipo-si, 15 Oct 2006; 1 శ , 1 우, Gujwa-eup, Hado-ri, 15 Oct 2006; 45 శ $^{\nearrow}$, 29 우 우, Seogwipo-si, 17 Oct 2006; $54 \sigma^{\nearrow} \sigma^{\nearrow}, 22$ 우 우, Seogwipo-si, 28 May 2007; $7 \sigma^{7} \sigma^{\nearrow, ~} 3$ 우 우, Gujwa-eup, Hado-ri, 28 May 2007; $3 \sigma^{\nearrow}$ శ, Jeju-si, Aewoleup, 30 May 2007; 3 శ $\sigma^{7}, 3$ 우 우, Seogwipo-si, 1 Jun 2007;

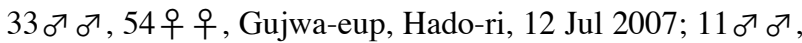
2 우 우, Gyeongsangnam-do: Ulsan, Ulju-gun, Seosaengmyeon, Jinha-ri, 11 Apr 2009; $1 \sigma^{\nearrow}$, Jeollanam-do: Yeong- 
A

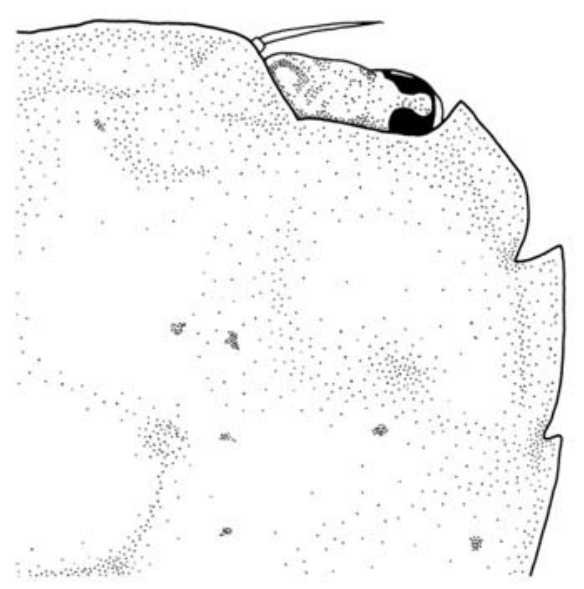

B

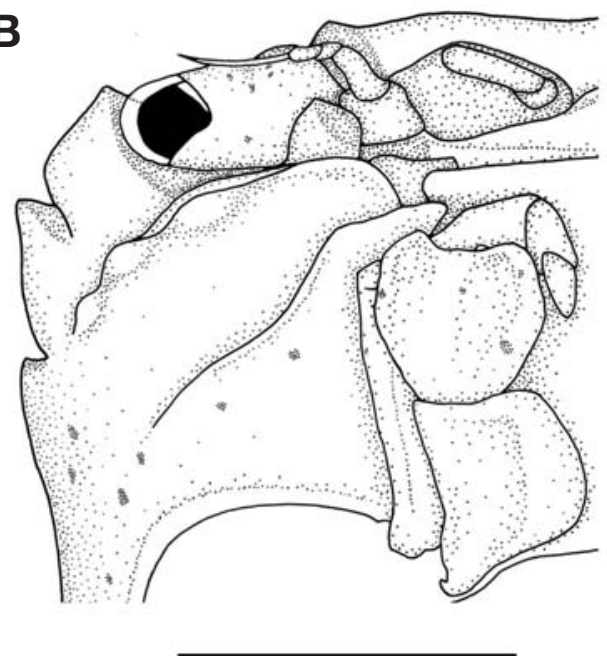

C

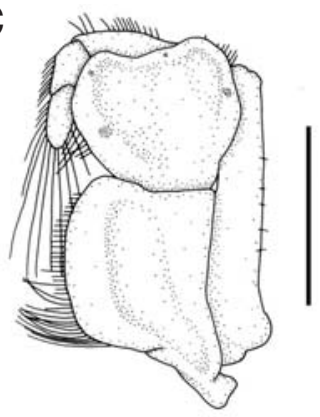

D
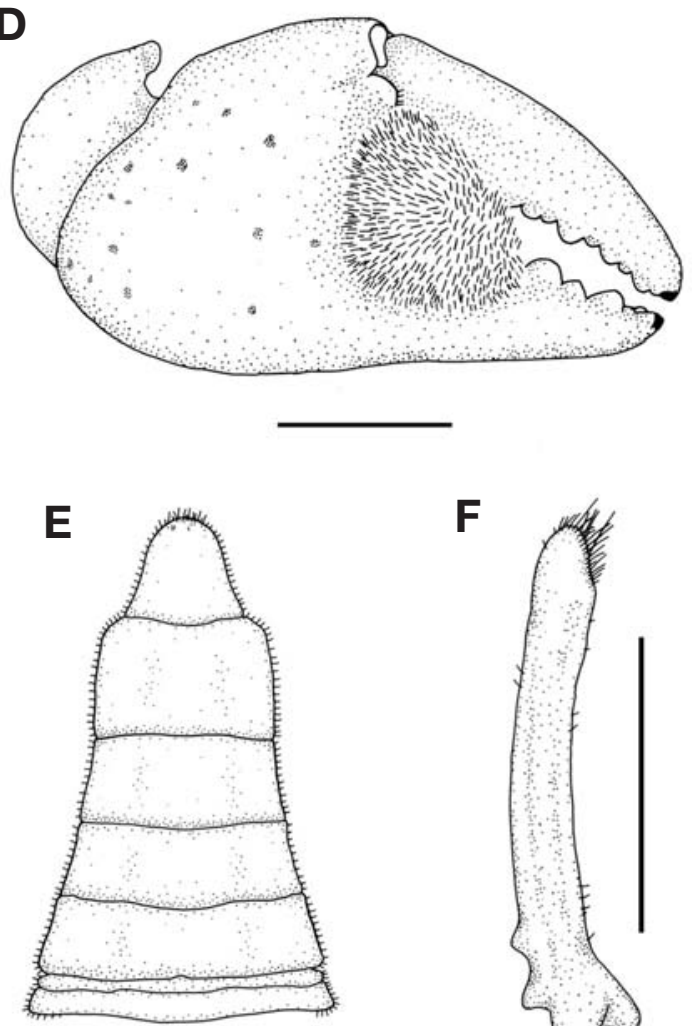

$\mathbf{F}$

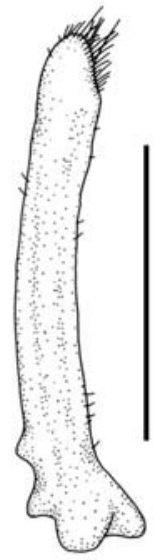

Fig. 2. Hemigrapsus takanoi Asakura and Watanabe, 2005, male (CL $17.6 \mathrm{~mm}, \mathrm{CW} 20.4 \mathrm{~mm})$. A, Cephalothorax, dorsal view; $B$, Cephalothorax, ventral view; C, Left third maxilliped; D, Right cheliped, outer view; E, Abdomen; F, First gonopod, external view. $\mathrm{CL}$, carapace length from the front to the posterior dorsal margin of the carapace; CW, width of the carapace measured at the widest part. Scale bars: $A-C, E=3 \mathrm{~mm}, D=5 \mathrm{~mm}, F=2 \mathrm{~mm}$.

gwang-gun, Nagwol-myeon, 16 Apr 2009; 44 ఠ ð , Gyeongsangnam-do: Goseong-gun, Donghae-myeon, Yongjeong-ri, 25 Apr 2009; 20 ठ ఠ , Masan-si, Jinjeon-myeon, Imyeong-ri, 25 Apr 2009; 7 ठ ఠ , Jeollanam-do: Jindo-gun, 17 Jun 2009; $106 \sigma^{\nearrow} \sigma^{\nearrow}$, Gyeongsangbuk-do: Pohang-si, Nam-gu, Daebomyeon, Daebo-ri, 10 Oct 2009; 76 ఠ ఠ do: Wando-gun, Wando-eup, Mangseok-ri, 20 Jun 2010.

Description. Carapace (Figs. 1A, 2A) quadrilateral, about 1.2 times as broad as long, width narrow posteriorly. Cardiac region, gastric region and branchial region divided by distinct $\mathrm{H}$-formed groove. Surface smooth and hairless. Lateral border bearing 3 distinct teeth in both directions, decreasing in size posteriorly. Supraorbital border deep and slightly angulated. Third maxillipeds (Fig. 2B, C) broad. Ischium quadrilateral, inner border circular. Margins of merus and ischium slightly convex.

Male chelipeds (Figs. 1, 2D) robust and smooth, each one almost same size; comparatively large and inflated. Basal of 
Table 1. The number of individuals and occurrence rates of Hemigrapsus takanoi and $H$. penicillatus in each coastal region of Korea

\begin{tabular}{lccccc}
\hline & \multicolumn{2}{c}{ H. takanoi } & & \multicolumn{2}{c}{ H. penicillatus } \\
\cline { 2 - 3 } & No. of individuals & Proportion (\%) & & No. of individuals & Proportion (\%) \\
\hline Western coast of Korea & 728 & 90 & 722 & 16 \\
Southern coast of Korea & 54 & 3 & 496 & 67 \\
Eastern coast of Korea & 26 & 100 & 125 & 17 \\
\hline \multicolumn{1}{c}{ Totals } & 808 & 743 & 100 \\
\hline
\end{tabular}

fixed finger having well developed bundle of soft setae, diameter of setal patches about 0.5 times as broad as dactylus length. Dactylus slightly curved to ventral, cutting edges with several well developed granulated teeth.

Ambulatory legs (Fig. 1) flatten. Dactylus, propodus and carpus having several rows of setae. Meri of first-third pereopods bearing single distal spine on extensor margin.

Male abdomen (Fig. 2E) consisting of seven plates, lateral limits divergent posteriorly, each lateral and distal border with short setae. Telson triangular.

G1 (Fig. 2F) stout, trigonal, straight, almost equal width; external part having dense setae.

Habitat. Live under boulders in intertidal zone.

Distribution. Japan, France, Spain, Belgium, Netherlands, Germany, and Korea (this study).

Remarks. Hemigrapsus takanoi closely resembles $H$. penicillatus even in the shape of their G1 (Sakai, 2007). These species can be distinguished by some characteristics: 1) $H$. takanoi has small spots on the cephalothorax, abdomen, third maxillipeds, and chelipeds. However, H. penicillatus has larger and darker spots; 2) in male, $H$. penicillatus has small size of setal patches, while $H$. takanoi has definite large size of setal patches (Asakura and Watanabe, 2005). The present specimens are well agreed with the original descriptions.

We investigated the distribution of these two species in the Korean peninsula. H. takanoi occurred mostly in the western coast of Korea, and appeared rarely in the south-eastern coast of Korea. $H$. penicillatus, however, mainly occurred in the southern coast (Table 1, Fig. 3).

Genus Sestrostoma Davie and Ng, 2007

$1 *$ Sestrostoma toriumii (Takeda, 1974) (Fig. 4)

Acmaeopleura toriumii Takeda, 1974: 17, figs. 2, 3; Davie, 1992: 351; Sakai, 2000: 1158, fig. 1i-j; Anker et al., 2005: 179.

Sestrostoma toriumii: Davie and Ng, 2007: 267.

Material examined. Korea: $11 \sigma^{7} \sigma^{\Im}(\mathrm{CW} \mathrm{3.3-5.7} \mathrm{mm,} \mathrm{CL}$

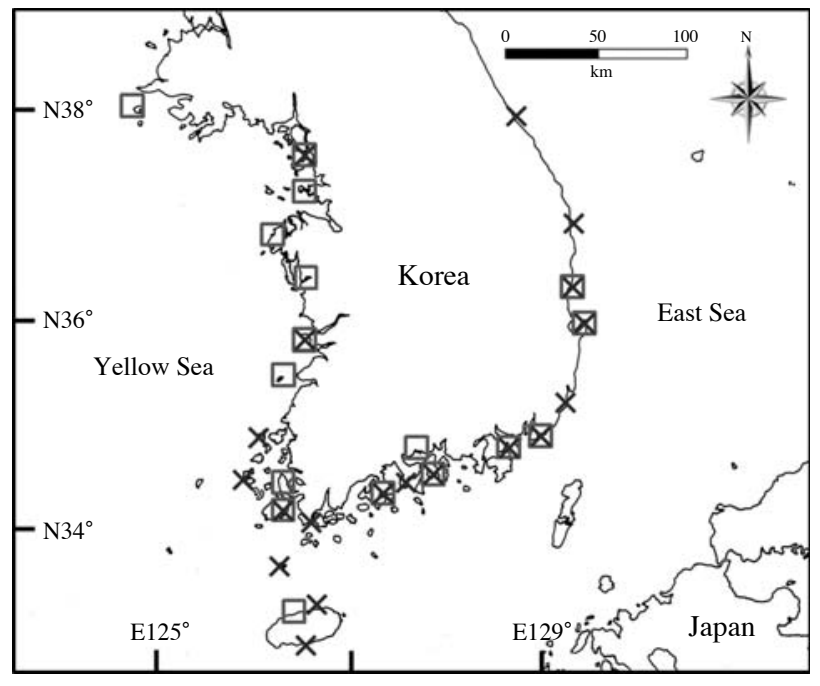

Fig. 3. The distribution of Hemigrapsus takanoi and $H$. penicillatus in the Korean peninsula $(\square, H$. takanoi; $\times, H$. penicillatus).

2.8-4.8 mm), 10 우 우 (CW 3.8-5.1 mm, CL 3.2-4.4 mm), Gyeongsangnam-do: Changwon-si, Daecheon-dong, 13 Jun 1999; 1 우, Busan, Dadae-dong, 28 Apr 1985; 1 지, 5 우 우, Changwon-si, Daecheon-dong, 23 Feb 1997; 1 우, Namhaegun, Seo-myeon, 1 Jul 1998; 8 ఠ ð dong-myeon, 2 Jul 1998; 1 ð , Namhae-gun, Gohyeon-myeon, 29 Jul 1999.

Comparative materials. Sestrostoma balssi: Korea: $1 \sigma^{7}$ (CW 8.47 mm, CL 6.89 mm), Incheon: Deokjeok-myeon, 12 Jun 1968; 7 శ $^{7}$ (CW 12.01-15.39 mm, CL 8.95-11.22 mm), 11 우 우 (CW 10.24-14.58 mm, CL 8.22-10.85 mm), Jeollabuk-do: Gunsan-si, Seamangeum, 24 Oct 2003.

Description. Carapace (Fig. 4A) quadrilateral, more or less angulated in median part of each lateral border, being slightly wider than long; 0.8-0.9 times as long as wide. Dorsum moderately and evenly convex in both directions. Surface naked and glabrous, but minutely and irregularly punctate under binocular microscope. Lateral and posterior borders

Korean name: ${ }^{1 *}$ 작은애기비단게 (신칭) 


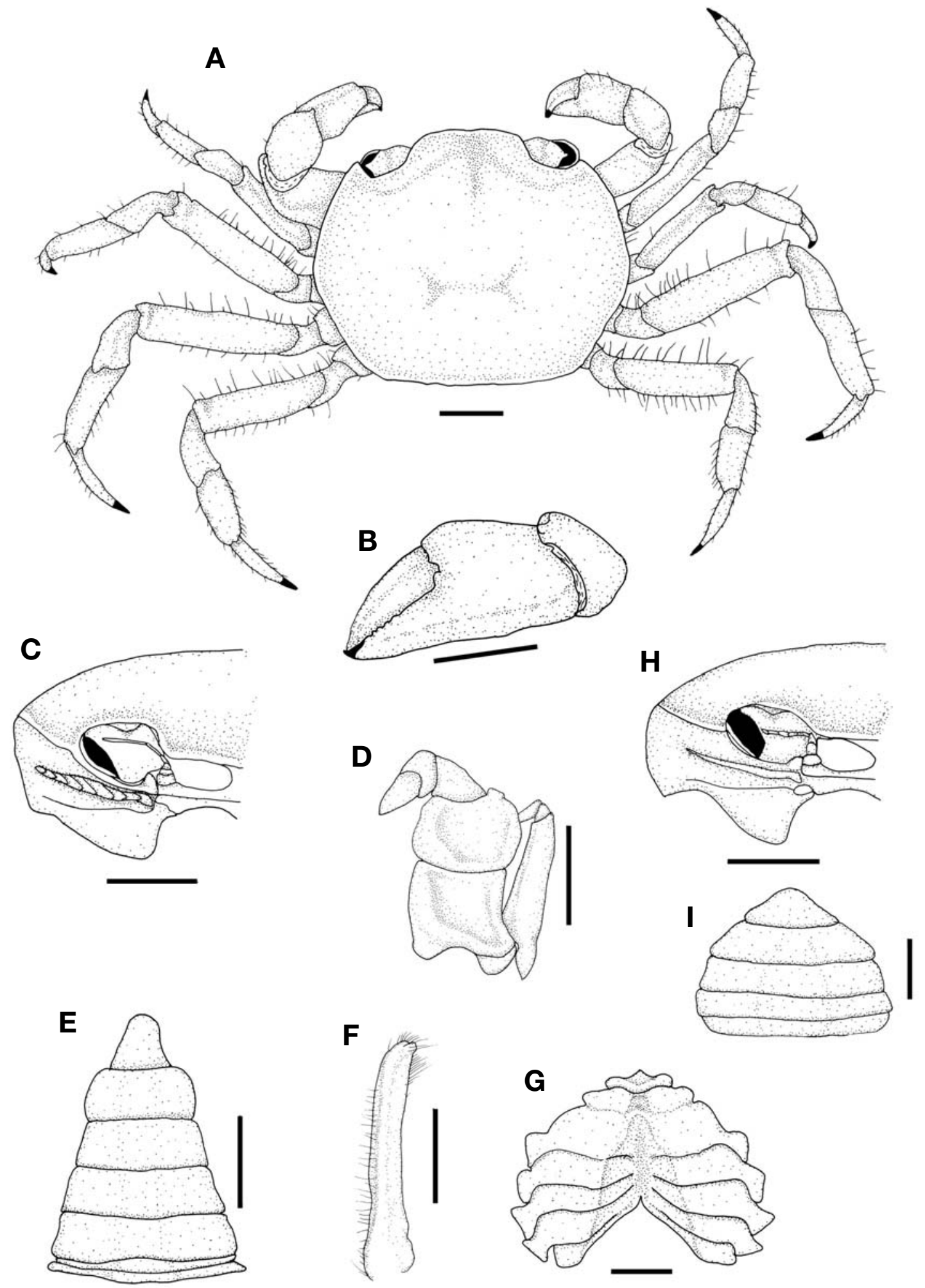

Fig. 4. Sestostroma toriumii (Takeda, 1974), male (CL $4.8 \mathrm{~mm}, \mathrm{CW} 5.7 \mathrm{~mm})$. A, Whole crab, dorsal view; B, Left cheliped, outer view; C, Frontal view of orbital region with suborbital crest; D, Left third maxilliped; E, Abdomen; F, First gonopod, external view; G, Sternal plates; H, Frontal view of orbital region with suborbital crest, female (CL $4.4 \mathrm{~mm}, \mathrm{CW} \mathrm{5.1} \mathrm{mm);} \mathrm{I,} \mathrm{Abdomen,} \mathrm{female.} \mathrm{CL,}$ carapace length from the front to the posterior dorsal margin of the carapace; $\mathrm{CW}$, width of the carapace measured at the widest part. Scale bars: A-C, E, G-I=1 mm, D, F=0.5 mm. 


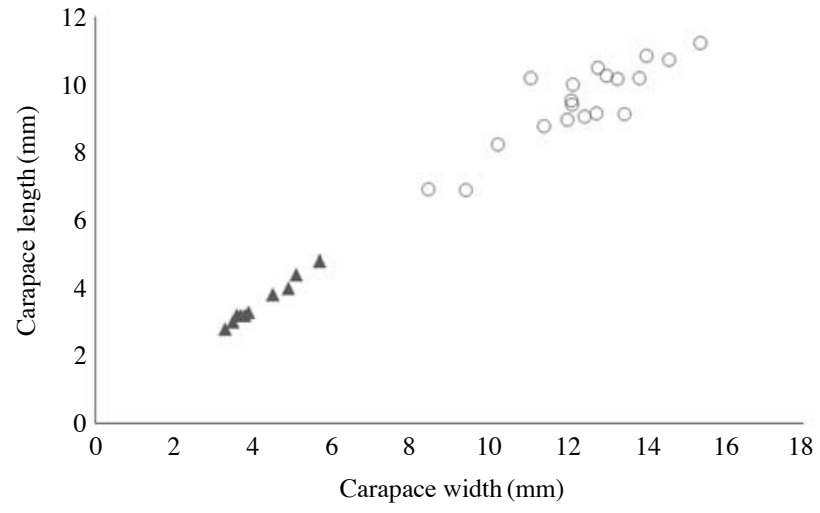

Fig. 5. Scatter plot of the carapace length plotted against the carapace width between Sestrostroma balssi (Shen, 1932) and S. toriumii (Takeda, 1974) in Korea. In S. balssi, the carapace length is $6.9-11.2 \mathrm{~mm}$ and the carapace width is $8.5-15.4 \mathrm{~mm}$. In contrast, the carapace length and width of the $S$. toriumii are 2.8-4.8 $\mathrm{mm}$ and 3.3-5.7 mm, respectively ( $O$, Sestrostoma balssi; $\mathbf{\Lambda}$, S. toriumii).

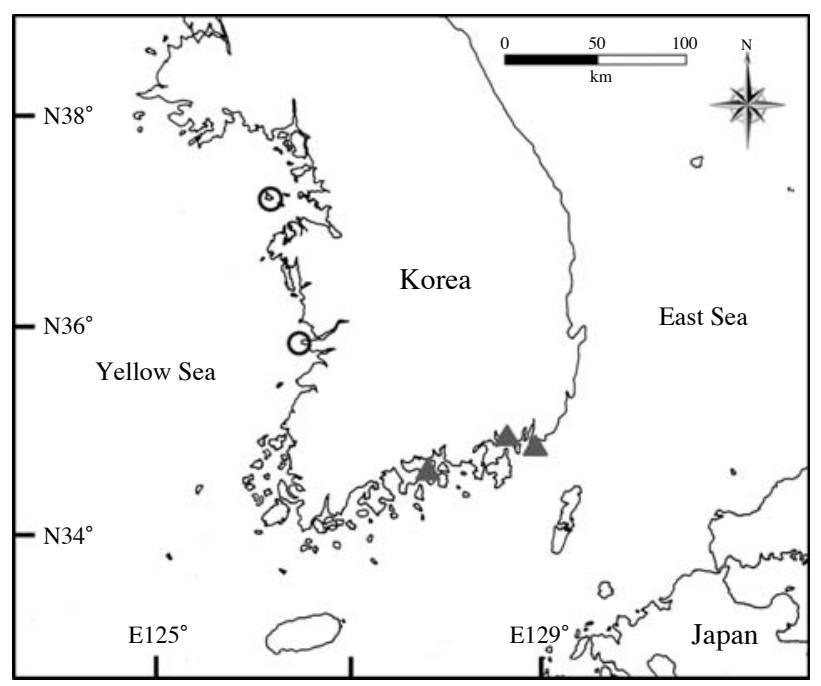

Fig. 6. The distribution of Sestrostoma balssi and $S$. toriumii in the Korean peninsula ( 0 , Sestrostoma balssi; $\mathbf{\Delta}$, S. toriumii).

narrowly rimmed; posterior border straight and only slightly narrower than frontal width. Front almost truncated only with dorsal obsolete depression in middle, being fringed with narrow rim; width 2.4-3.5 mm and just one fourth of carapace width. Suborbital ridge of male (Fig. 4C) composed of nine smooth and transverse tubercles, but those of female (Fig. 4H) forming one crest. Third maxillipeds (Fig. 4D) broad and completely closed in buccal cavern. Ischium and merus widely sculptured with large depression. Palp stout with extremely long apical hairs exceeding posterior end of ischium in natural position.

Chelipeds (Fig. 4B) minutely granulated, equal and large with inflated palms; outer surface of palm ornamented transverse ridge, with small tuft comparatively slender and fringed with sparse hairs. Tips of fingers meeting, or crossing only slightly.

Ambulatory legs (Fig. 4A) comparatively slender and fringed with sparse hairs; both borders of meri being covered with minute granules.

Anterior sternal plates (Fig. 4G) with distinct medial groove.

Male abdomen (Fig. 4E) narrowly triangular. Female abdomen (Fig. 4I) broadly triangular.

G1 (Fig. 4F) long, slender, with corneous process apically. Gonopore of female operculate, circular in shape.

Habitat. Mud and coarse sand, associated with thallassinid Upogebia major and echiurid Ochetostoma erythrogrammon. Colour. Preserved specimens in $75 \%$ ethyl alcohol are cream or light brown colored.

Distribution. Japan (Onagawa Bay, Yamaguchi Bay), Hong Kong and south coast of Korea (this study).

Remarks. According to the original description of Takeda (1974), the suborbital crest as a stridulatory organ of Sestostroma toriumii in males consists of 9 tubercles. As the sexual differences of this species, the female has a plain ridge without granulation. The present specimens agree very well with the original description.

The carapace of $S$. toriumii looks very similar to $S$. balssi. Davie and $\mathrm{Ng}$ (2007) mentioned that the adult body size differs clearly between the two species: Sestrostoma balssi reaches as large as $17 \mathrm{~mm}$ of carapace width, while $S$. toriumii is a smaller species with the largest specimens attaining a maximum carapace width of approximately $8 \mathrm{~mm}$. In the present study, two species also showed a remarkable difference on the size of the carapace as depicted in the morphometric analysis (Fig. 5). In addition, the current specimens of $S$. toriumii are smaller (approximately $3.3-5.7 \mathrm{~mm}$ ) than the size of the carapace mentioned in the description of Davie and $\mathrm{Ng}$ (2007). The distribution of $S$. toriumii is limited to the southern coast of the Korean peninsula (Fig. 6).

\section{ACKNOWLEDGMENTS}

The authors thank Prof. Peter K. L. Ng (National University of Singapore) for allowing the second author to use facilities during visit to Raffles museum, Singapore. This research was supported by a grant from Marine Biotechnology Program Funded by Ministry of Land, Transport and Maritime Affairs of Korean Government. 


\section{REFERENCES}

Anker A, Murina GV, Lira C, Caripe JAV, Palmer AR, Jeng MS, 2005. Macrofauna associated with echiuran burrows: a review with new observations of the innkeeper worm, Ochetostoma erythrogrammon Leuckart and Rüppel, in Venezuela. Zoological Studies, 44:157-190.

Asakura A, Watanabe S, 2005. Hemigrapsus takanoi, new species, a sibling species of the common Japanese intertidal crab H. penicillatus (Decapoda: Brachyura: Grapsoidea). Journal of Crustacean Biology, 25:279-292.

Davie PJF, 1992. A new species and new records of intertidal crabs (Crustacea: Brachyura) from Hong Kong. In: Proceedings of the Fourth International Marine Biological workshop: The Marine Flora and Fauna of Hong Kong and Southern China (Ed., Morton B), Hong Kong University Press, Hong Kong, pp. 345-359.

Davie PJF, Ng PKL, 2007. Two new subfamilies of Varunidae (Crustacea: Brachyura), with description of two new genera. The Raffles Bulletin of Zoology, Supplement, 16:257-272.

De Haan W, 1833-1850. Crustacea. In: Fauna Japonica sive Descriptio Animalium, Quae in Itinere per Japoniam, Jussu et Auspiciis Superiorum, qui Summum in India Batava Imperium Tenent, Suscepto, Annis 1823-1830 Collegit, Notis, Observationibus et Adumbrationibus Illustravit (Ed., von Siebold PF). Lugduni-Batavorum, Leiden, pp. 1-243.

Kim HS, 1973. Illustrated encyclopedia of fauna and flora of Korea, Vol. 14. Anomura: Brachyura. Samwha Publishing Co., Seoul, pp. 1-649.

Miers EJ, 1879. On a collection of Crustacea made by Capt. H. C. St. John, R. N. in the Corean and Japanese seas. Part 1. Podophthalmia. Proceedings of the Zoological Society of London, 1879:18-61.

Miyake S, Sakai K, Nishikawa S, 1962. A fauna-list of the decapod Crustacea from the coasts washed by the Tsushima Warm Current. Records of Oceanographic Works in Japan,
Special Number, 6:121-131.

Ng PKL, Guinot D, Davie PJF, 2008. Systema Brachyurorum: Part 1. An annotated checklist of extant brachyuran crabs of the world. The Raffles Bulletin of Zoology, Supplement, 17: $1-286$.

Rathbun MJ, 1929. New and rare Chinese crabs. Lingnan Science Journal, 8:75-104.

Sakai K, 2000. On the occurrence of three species of crabs on Shikoku Island, Japan, and a new species, Pinnotheres taichungae nov. spec., from Taiwan (Decapoda, Brachyura). Crustaceana, 73:1155-1162.

Sakai K, 2007. Comments on an invalid nominal species, Hemigrapsus takanoi Asakura \& Watanabe, 2005, a synonym of Hemigrapsus penicillatus (De Haan, 1835) (Decapoda, Brachyura, Grapsidae). Crustaceana, 80:503-508.

Sakai T, 1976. Crabs of Japan and the adjacent seas. Kodansha Ltd., Tokyo, pp. 1-773.

Shen CJ, 1932. The brachyuran Crustacea of North China. Zoologica Sinica, Series A, 9:1-321.

Takano M, Ikeda M, Kijima A, 1997. Biochemical and morphological evidence of two sympatric forms, interpreted as sibling species, in the estuarine grapsid crab Hemigrapsus penicillatus (De Haan). Benthos Research, 52:111-117.

Takeda M, 1974. Accounts of some rare crabs from Mutsu Bay, with description of a new grapsid from Onagawa Bay. Bulletin of the Marine Biological Station of Asamushi, Tohoku University, 15:13-21.

Yamasaki I, Doi W, Mingkid WM, Yokota M, Strüssmann CA, Watanabe S, 2011. Molecular-based method to distinguish the sibiling species Hemigrapsus penicillatus and Hemigrapsus takanoi (Decapoda: Brachyura: Varunidae). Journal of Crustacean Biology, 31:577-581.

Received December 14, 2012 Revised January 30, 2013 Accepted February 7, 2013 